\title{
The tale of the apewoman who craved to become a siren: A natural way to combat radically hirsutism
}

\section{Lorenzo Martini}

University of Siena, Department of Histology and Embryology, Via A. Moro 2, 53100 Siena, Italy

Corresponding author: Lorenzo Martini, M.Sc., E-mail: martinil163@libero.it

\begin{abstract}
Purpose of this odd study is to determine if it really exists a way to combat definitively hirsutism, a disease that creates social and anthropological problems in women and men. Excessive and periodical epilations or depilations are not suggestible at all, since hair risks to become more and more harsh and coarse, skin too coriaceous and too often even hair ingrowth may occur. We have had the fortune to try to treat an ape woman who decided to become completely and indeciduously glabrous, for sake of her job, and thanks to an old Brazilian Formulary for Apothecaries, I discovered that there is a strange fruit from South America that when rubbed on epilated skin, avoids the hair re-growth, periennally. We have scrutinized which are the chemical constituents of this fruit and I have had the chance to prepare a natural orpiment that can loose the problem of hirsutism.
\end{abstract}

Key words: Hirsutism; Monkeypot; K5 and Kl4 keratins; Immunofluorescence assays; BSA-PBS

\section{INTRODUCTION}

The idea of conceiving a natural remedy apt to defeat radically hirsutism in woman (and even in man) was borne out of an amusing fact: an ape woman belonging to a travelling circus asked me to help her to avoid the continuous re-growth of her hair on all her body, since their chiefs had decided to transform her in a siren, a sort of sylph-acrobat for the next seasons of shows.

She had tried to avoid her hair re-growth by employing all types of drastic depilatories and by rubbing strongly with pumice, but all these experiences resulted bootless.

She had even discovered that in fifties workers in firms producing polymers of chloroprene, handling continuously the monomers and dimers of chloroprene, tended all to become bald irrevocably, and so she attempted to evoke a full baldness by rubbing bags and cuts of soft polypropylene onto her body hair, previously wetted by strong alkaline treatment (the same method our local housekeepers use to pickle olives) and effectively she beheld that after two weeks she was completely glabrous, albeit her epidermis became coriaceous and harsh, and consequently she was forced to spend an avalanche of money for treating her skin with lotions containing allantoin and synthetic moisturizers.

She chewed seeds of Mimosa pudica (containing leucenin or leucenol) and loss all hair, nevertheless her hair regrew stronger and coarser after having stopped the ingestion of seeds of Mimosa (since they are slightly poisonous too).

She tried even to swallow coumarins (both natural and synthetic, like warfarin) as she had read in an ancient text that after seven weeks from the suspension from taking these drugs, she would have had all the body completely glabrous.

And indeed she obtained only that her INR became so high (more than $>4$ ), so that her wounds needed weeks to heal definitively.

Now, We had discovered antecedently that there is a Brazilian fruit that gives an oil (and the fruit is similar 
to an almond) that when rubbed onto skin, leaves it glabrous and completely hairless.

The fruit is the Lecithys pisonis yclept coco de mono (the Anglo- Saxons call it monkeypott) and this almond contains a mix of triterpenes $(8 \alpha$ - and $\beta$-amyrin, uvaol and erythrodiol, ursolic and oleanolic acids and $3 \beta$-friedelinol).

Legend has it that the trivial name monkeypott derives from an ancient local proverb: "a wise old monkey doesn't stick its hand into a pot" of Lecithys pisonis, obviously, because of its oral toxicity.

Some Brazilian AA [1] retain that that the chief antimitotic activity (with regards to the piliferous bulb) is due to the combinaison of ursolic and oleanolic acids, and thus all plants that contain these two terpenes should be interesting to treat hirsutism as well.

Except Cherry laurel leaves Prunus laurocerasus L, that is considered a bane in cosmetic items, the following herbs present a huge amount of ursolic acid:

Holy Basil, Ocimum sanctum L., Bilberry Vaccinum myrtillus L., Devil's Claw Harpagophytum procumbens, Elder Flowers (European Variety) Sambucus nigra L., Peppermint leaves Mentha piperita L., Periwinkle Vinca minor L., Lavender Lavandula augustifolia Mill. Oregano Origanum vulgare L., Thyme Thymus vulgaris L., Hawthorn Crataegus laevigata.

In addiction, there are other herbs which contain highest amount of oleanolic acid.

Except Prosopis glandulosa, Phordendron juniperinum, Hyptis capitata, which are not retrievable on the common market, and moreover Phytolacca Americana (cause of its elevated internal and moreover topical toxicity) all these others do contain oleanolic acid:

Sygizium spp. (Sygizium aromaticum, idest clove), Garlic, Olea europaea, Rosa woodsii, (idest Wood rose or palissandre (the essential oil derived from leaves).

So it has been easy to prepare a mildly alcoholic lotion (it could be appealed "orpiment") made of all these essential oils and tinctures.

The woman had to depilate her entire body by a strong wax made with colophon (pix graeca) and yellow beeswax (75.25) as suggested from Cosmeticologists since immemorial times as the best way to remove superfluous hair in woman's and man's body.

Now, it is mandatory to insert a slight digression, that can come in handy to dermatologists as well.

Effectively Waxing is the most popular hair removal technique till date. Waxing or hair removal is not something new. A silky, smooth and hairless body was a standard of beauty, youth and innocence for women in Egypt. The wife of divine Pharaoh set an example and then the trend was followed by every woman in Egypt. They used a sticky emulsion made up of honey and oil. Later on Greeks followed the trend. The best proof are Greek sculptures of women - so shiny and smooth. Romans also followed suit and girls began hair removal with the help of "tweezers" and also depilatory cream.

Nowadays even electric epilators exist that promise too often the missing regrowth after manifolds uses, howbeit many are the sources that declare the following pro and contra of epilatory waxes when elected versus electric epilators, like these.

\section{Advantages of Waxing}

It's a very effective method of hair removal in large amount at one time.

Waxing can make hairless skin last up to two months.

\section{Disadvantages of Waxing}

Although waxing is by far the best method of hair removal, it can irritate the skin, causing redness and bumps for those with sensitive skin and moreover the process of waxing can be messy and sticky.

\section{Disadavantages of Electric Epilators}

Using an epilator can be painful the first few times.

Some people may experience problems with missed or ingrown hairs as well.

For this reason, complete epilation by electric devices, both in women and men, I deem, is regrettable cause of the occurrence of ingrown hairs, that represents a serious concern not only for beauticians but even for dermatologists: hirsutism may become paradoxical. 


\section{MATERIALS AND METHODS}

As we introduced in the antefact, the ape-woman underwent a complete epilation by using a rosin: beeswax epilatory and instead of waiting the 2 months forecasted for a modest re-growth, I have preferred to have an immunofluorescent test made on histological samples where some hair follicle were collected, by other colleagues of mine, who had chosen to remain incognito, after only two weeks of experimentations.

Before to explain the experiment made by my colleagues histologists, it is useful to declare that Keratins are especially abundant in stratified squamous epithelial tissues, where they compose the major differentiationspecific products of these cells.

For instance, type I keratins (K9-K19) are relatively small, and acidic, whereas type II keratins (Kl-KS) are larger and more basic [1-7]. In epithelial tissues, keratins are differentially expressed as specific pairs of type I and type II proteins, both of which are essential for filament formation [8,9]. In epidermis, tongue, cornea and esophagus, and hair follicle in general, K5 and $\mathrm{Kl} 4$ are the pair expressed in the basal, mitotically active layer, and this pair has been considered to be a biochemical marker of stratified squamous epithelia and index of safe condition for tissue regeneration or hair growing, as in our case [5].

In the hair follicle, the programs of differentiation and patterns of keratin expression are far more complex than in other stratified squamous epithelia [5,10-13].

Surrounding the hair shaft are two sheaths, an outer (ORS) and an inner ORS) root sheath. Most of the ORS originates from one to two layers of cells on the surface of the mid-region of the hair bulb [14]. At the beginning of each hair cycle, these progenitor ORS cells divide rapidly and give rise to a population of selfpropagating cells that extend along the outer surface of the ORS to approximately half way up the follicle [14].

ORS cells in this lower region seem to migrate both upwards and inwards as they differentiate. In contrast, cells of the upper portion of the ORS migrate predominantly inwards as they differentiate.

The pathways of differentiation leading to the production of the hair are characteristic of other stratified squamous epithelia in that unique sets of keratins are produced by the fully differentiated cells of these structures [5,13]. Despite major differences in the behavior of the mitotically active epithelial cells of the hair follicle, it has been assumed widely that these cells are similar in their biochemistry to basal epidermal cells, those presenting the major percentage of $\mathrm{K} 5$ and Kl4 keratins.

Several lines of recent evidence suggest that levels of K5 and K14 in mitotically active cells may correlate with their relative degree of differentiation: An increase in expression of K14 was found to accompany commitment of embryonic basal cells to differentiate into basal epidermal cells and thus to the hair growth, and a reduction in expression of KI4 seemed to be associated with misleading hair growth or definitive missing hair genesis [15].

The investigation upon the degree of $\mathrm{K} 5$ and $\mathrm{Kl} 4$ keratin expression on hair follicle appears to be the best way to evaluate the definitive condition of baldness or situation of dramatic evidence of no-re-growth of hair as well.

Achieving to evaluate the degree of expressions of $\mathrm{K} 5$ and $\mathrm{Kl} 4$ keratins is the goal in order to put in evidence the presence or the absence of $\mathrm{K} 5$ and Kl4 keratins expressions in hair bulb, and so several methods are available for this purpose. Presently the best investigation is reputed to be the BSA and PBSImmunofluorescence assay (by FM, Fluorescence Microscopy), directly on the histological sample of the hair follicle.

Immunofluorescence (IF) is a powerful method for visualizing intracellular processes, conditions and structures. IF preparations, as aforesaid, can be analyzed by a simple fluorescence microscope.

The centerpiece of an IF experiment is a combination of two different components: a specific antibody, which is used to form an immune complex to mark the desired molecules - for hair samples BSA and PPS (Bovine serum albumine and phosphate buffer saline) are welcome - to stratify in the slide to put in the fluorescent microscope and then a fluorochrome, which is coupled to the immune complex and therefore the target structures during microscopy may be easily visualized.

To examine the pattern of K14 expression in the specific case of the ape woman that became glabrous after total epilation and after two weeks of experimentation (idest 
applying the natural lotion I prepared for her) at the level of fluorescent microscopy, I let my colleagues stain the sections of the hair with the mix BSA-PBS (the antibody that links to the 15 amino acid residues of the carboxy terminus of human KI4) and use and Immunogold as fluorochrome to determine the degree of $\mathrm{K} 5$ and $\mathrm{K} 14$ expressions and make all the measurements by F.M. (fluorescent microscope).

\section{RESULTS}

Results show infallibly that after two weeks of application of my natural "orpiment" the K5 and K14 expressions were finally ceased so it can be specifically confirmed the definitive hair re-growth cessation.

\section{DISCUSSION}

Beauticians and aetheticians surely could object that applying a remedy capable to inhibit hair re-growth, they could close up their shop, but this is a case of severe manifestation of hirsutism ribellis and for this We suppose the lotion could be appreciated even by dermatologists and aesthetical surgeons.

\section{CONCLUSIONS}

The ape woman underwent a complete epilation (that was supposed to inhibit hair re-growth for 8 weeks), but she decided to follow my suggestions and so experimented the natural orpiment with the herbal extracts.

She used to spread the lotion onto all the areas of her body and after two weeks We have stated (thanks to the help by histologists) that the hair re-growth is definitively exorcised.

\section{ACKNOWLEDGEMENTS}

Thank you for Doctor from Department of Histology and Embryology, University of Siena, Italy

\section{Statement of Human and Animal Rights}

All procedures followed were in accordance with the ethical standards of the responsible committee on human experimentation (institutional and national) and with the Helsinki Declaration of 1975, as revised in 2008.

\section{Statement of Informed Consent}

Informed consent was obtained from all patients for being included in the study.

\section{REFERENCES}

1. Fuchs E, Green H. Changes in keratin gene expression during terminal differentiation of the keratinocyte. Cell. 1980;19:1033-42.

2. Fuchs E, Marchuk D. Type I and type II keratins have evolved from lower eukaryotes to form the epidermal intermediate filaments in mammalian skin. Proc Natl Acad Sci USA.1983;80:5857-61.

3. Fuchs E, Coppock SM, Green H, Cleveland DW. Two distinct classes of keratin genes and their evolutionary significance. Cell. 1981;27:75-84.

4. Fuchs E, Tyner AL, Giudice GJ, Marchuk D, Ray Chaudhury A, Rosenberg M. The human keratin genes and their differential expression. Curr Top Dev Biol. 1987;22:5-34.

5. Moll R, Franke W, Schiller D, Geiger B, Krepler R. The catalog of human cytokeratins: patterns of expression in normal epithelia, tumors and cultured cells. Cell. 1982;31:11-24.

6. Moll R, Held HW, Franke WW, Moll R. Patterns of expression of trichocytic and epithelial cytokeratins in mammalian tissues. II1. Hair and nail formation during human fetal development. Differentiation. 1988;39:167-84.

7. Moll R, Moll I, Wiest W. Changes in the pattern of cytokeratin polypeptides in epidermis and hair follicles during skin development in human fetuses. Differentiation. 1982;23:170-8.

8. Eichner R, Bonitz P, SunT-T. Classification of epidermal keratins according to their immunoreectivity, isoelectric point, and mode of expression. J Celt Biol. 1984;98:1388-96.

9. Eichner R, Sun T-T, Aebi U. The role of keratin subfamilies and keratin pairs in the formation of human epidermal intermediate filaments. J Cell Biol. 1986;102:1767-7.

10. Steinert PM. Structural features of the alpha-type filaments of the inner root sheath cells of the guinea pig hair follicle. Biochemistry. 1978;7:5045-52.

11. Steinert PM, Rogers GE. Characterization of the proteins of guinea-pig hair and hair follicle tissue. Biochem J. 1973;135:759-71.

12. Crewther WG, Dowling LM, Gough KH, Marshall RC, Sparrow LG. The microfibrillar proteins of alpha-keratin. In Fibrous Proteins: Scientific, Industrial and Medical Aspects, Volume 2. D. A. D. Parry and L. K. Creamer, editors. Academic Press, New York. 1980;151-9.

13. Crewther WG, Dowling LM, Parry DAD, Steinert PM. The structure of intermediate filaments. Int J Biol Macromol. 1983;5:267-82.

14. Chapman RE, Dowries AM, Wilson PA. Migration and keratinization of cells in wool follicles. Austr J Biol Sci. 1980;33:587-603.

15. Roop DR, Krieg TM, Mehrel T, Cheng CK, Yuspa SH. Transcriptional control of high molecular weight keratin gene expression in multistage mouse skin carcinogenesis. Cancer Res. 1988;48:3245-52.

Copyright by Lorenzo Martini. This is an open access article distributed under the terms of the Creative Commons Attribution License, which permits unrestricted use, distribution, and reproduction in any medium, provided the original author and source are credited.

Source of Support: Nil, Conflict of Interest: None declared. 